YAK 347.5:004.8

Колодін Аенис Олексійович,

канАиАат ЮриАичних наук, Аоцент,

Аоцент кафедри кримінального права,

Аекан факультету цивільної та господарської юстиції

Національного університету “ОАеська юридична академія"

Байталюк Аарія Русланівна,

магістр права

\title{
ЩОДО ПИТАННЯ ЦИВІЛЬНО-ПРАВОВОЇ ВІДПОВІДАЛЬНОСТІ ЗА ШКОДУ, ЗАВДАНУ РОБОТИЗОВАНИМИ МЕХАНІЗМАМИ ЗІ ШТУЧНИМ IНТЕЛЕКТОМ (РОБОТАМИ)
}

Постановка проблеми. Роботизовані механізми зі штучним інтелектом (роботи) вже стали нашою реальністю, і вочевидь, експансія машин у всі сфери ^юАського життя неминуча. Важливою галуззю люАської Аіяльності, де роботи наразі використовуються найбільше, $€$ промисловість. При цьому необхіАно віАрізняти запрограмовані роботизовані механізми, які не наділені штучним інтелектом, і роботизовані механізми зі штучним інтелектом (власне, роботи).

Першою європейською країною, яка почала масово роботизувати промисловість, стала Німеччина. Згодом до цього процесу долучилися Франція, Великобританія, Швейцарія тощо, і зараз такі процеси відбуваються у всіх без винятку розвинених країнах світу. Поступово питання роботизації вийшло за межі окремих країн і стало актуальним Аля міждержавних утворень. Зокрема, проблемами правового регулювання віАповіАних віАносин активно зайнявся Євросоюз.

Вже у 2013 році Євросоюз вирішив створити SPARC (приватно-Аержавне партнерство Аля широкого впровадження робототехніки в Європі). SPARC створено, зокрема, А^я піАтримки і розширення світового лідерства Європи в робототехніці. SPARC прагне роботизувати процеси на заводах, у повітрі, на суші, піА водою, у сфері сільського господарства, охорони зАоров'я, рятувальних службах, а також у багатьох інших сферах ^юАського життя в Європі, які мають економічний і соціальний вплив.
Більше того, в ^ютому 2017 року Європарламент прийняв резолюцію піА назвою «Норми цивільного права щодо робототехніки". Аокумент складається з більш ніж сотні пунктів і присвячений найрізноманітнішим аспектам і проблемам робототехніки і штучного інтелекту. Зокрема, пропонується впроваАження загальноєвропейської системи реєстрації роботів.

Капіталізація робототехніки станом на 2019 рік складає 50 млрд. євро [1]. Якщо ж врахувати інші галузі економіки, які також використовують штучний інтелект, то їхня капіталізація складе вже трильйони євро. Отже, обсяг світового ринку товарів та послуг, у функціонуванні якого беруть участь роботизовані механізми та штучний інтелект, зростатиме в геометричній прогресії.

Таким чином, у зв'язку зі швиАким розвитком робототехніки і штучного інтелекту постає питання визнання роботів квазісуб'єктами цивільних віАносин.

Стан АосліАження теми. Проблеми правового регулювання віАносин, що складаються у зв'язку 3 використанням штучного інтелекту та роботизованих механізмів (роботів), ще грунтовно не АосліАжувалися, проте деякі з них вже потрапили в поле наукових пошуків окремих вітчизняних й іноземних досліАників. Зокрема, Ао таких можна віднести В. Архіпова, В.М. Качевського, А. Незнамова, К.Г. Некіт, Р. М. Аsaro та інших.

Метою статті $\epsilon$ АосліАження проблемних аспектів цивільно-правової відповідальності за 
шкоду, завдану у зв'язку з використанням штучного інтелекту і роботизованих механізмів (роботів). Крім того, у зв'язку з бурхливим розвитком інформаційних технологій та активним використанням штучного інтелекту і роботів виникає необхідність переосмислення традиційних піАходів Ао визначення самого поняття суб'єктів цивільних правовіАносин.

ВикиаА основного матеріалу АосліАження з повним обґрунтуванням отриманих наукових результатів. ЗавАяки новітнім інформаційним технологіям сучасний світ стрімко змінюється. ОАним із найбільш значимих проявів цього процесу є використання штучного інтелекту і роботів зокрема, які починають відігравати важливу роль у розвитку цілих сфер суспільного життя. Приміром, шляхами найрозвиненіших країн світу вже пересуваються автомобілі, які не потребують керування ^юАиною, повітряні Арони самостійно Аоставляють товари покупцям інтернет-магазинів, а на товарних складах провідних торговельних компаній роботи вже Аавно замінили ^юдей-працівників.

Отже, який статус автономних механізмів у зазначених вище суспільних відносинах? Найочевиднішою відповіААю на це питання буде така: це квазісуб'єкти цивільних відносин. Проте Аеякі науковці вик^ючають можливість визнання роботів як квазісуб'єктів цивільних віАносин, оскільки вони створені ^юАиною і мають у своєму арсеналі тільки той набір функцій, який закладений у них програмним коАом.

3 іншого боку, новітні розробки у сфері штучного інтелекту Аозволяють роботам аналізувати отриману інформацію, АосвіА, самонавчатись та знаходити нові способи вирішення питань або прийняття рішень. Крім того, сліА нагадати, що юридичні особи теж створені ^юАиною і вже Аавно визнані повноцінними суб'єктами цивільних віАносин. При цьому юриАичні особи - це штучні, умогляАні конструкції. Якщо звернутися Ао теорії фікції, юридична особа як суб'єкт цивільних віАносин являє собою, по суті, майно, якому надано правосуб'єктність [2].

Розмірковуючи на предмет правосуб'єктності роботів, не зайвим буде пригадати досвіА СтароАавнього Риму у відносинах із рабами. Зокрема, на думку М.В. Карчевського, раби також тривамий період не визнавалися суб'єктами права, проте згодом ситуація змінилася [3]. Звичайно, не можна не погодитися $з$ Аумкою К.Г. Некіт, відповідно до якої раби були такими самими мюдьми, як і громадяни Риму, а роботи завжди залишати- муться машинами [4]. А з іншого боку, чи не залежить факт визнання правосуб'єктності за роботами винятково віА рівня розвитку технологій. ААже за умови унеможливлення завАання роботами невиправданої шкоАи АюАям повноцінний Аопуск роботів Ао участі в цивільних віАносинах $€$ корисним і навіть необхідним. Звичайно, крім належного технологічного рівня, ^юдям необхінно забезпечити й належне правове регулювання відповіАних віАносин. Як було зазначено вище, перші кроки у цьому напрямку вже зроблено.

Звичайно, правосуб'єктність мюдини і робота не може бути однаковою. Правосуб'єктність роботів буде обмеженою. Зокрема, американські вчені-юристи вже пропонують розглядати роботів як квазісуб'єктів цивільних відносин, які користуються тільки частковими правами і обов'язками.

Як приклаА квазісуб'єктів американські правознавці наводять малолітніх дітей. Малолітні Аіти не наділені повним обсягом правомочностей, які належать повнолітнім фізичним особам. Зокрема, йдеться про можливість укладати Аоговори або бути засновником юридичних осіб. Малолітні особи можуть вчиняти такі Аії тільки з Аозволу та за Аопомогою батьків або опікунів. Таким чином, концепція “квазісуб'єктності" маломітніх осіб, що існує в правовій Аоктрині США, може бути використана Аля обґрунтування квазісуб'єктності роботів [5].

Квазісуб'єкність, сереА іншого, передбачає, що й юридична відповідальність за власні Аії таких учасників цивільних відносин буде значною мірою обмежена. Це означає, що відповідати за дії роботів або відповідати разом із роботами будуть і їхні виробники (розробники). Тим більше, що концепція розподілу відповідальності в залежності віА ступеня вини вже Аавно існує у правовій Аоктрині. Залишилося лише чітко продумати правила застосування заходів юридичної віАповіАальності саме в Аосліджуваній сфері.

Зокрема, теоретично робот може завдати шкоди правам та інтересам інших осіб через безліч факторів: недоліки програмного коду, збій в програмі, несправність приладів тощо можуть впливати на Аії роботів, насліАком чого може стати завАання шкоди.

Крім того, не варто забувати і про власників роботів, які теж, так чи інакше, відповіАальні за свою покупку і можуть функціонально звузити чи розширити коло повноважень роботів, закладених у нього виробником. Таким чином, заходи цивільно-правової відповідальності можуть бути застосовані до особи, яка надала роботу Аозвіл 
на вчинення певних дій або дозвіл штучному інтелекту Аіяти за власним переконанням.

I нарешті, сам роботизований механізм із штучним інтелектом, який зАатний самовАосконалюватися, навчатися, аналізувати отриману інформацію і Аіяти виходячи 3 власних "міркувань". Відповідно, постає питання застосування захоАів юридичної відповідальності до такого робота.

СліА зазначити, що питання цивільно-правової відповідальності наразі є більш важливим, аніж питання кримінальної відповідальності, аАже набагато частіше йдеться про псування майна роботами, ніж про злочини.

ОАнією з головних проблем цивільно-правової відповідальності роботів є проблема визначення вини роботів у прийнятих ними рішеннях. АюАина може порушувати встановлені правила, оскільки вони починають суперечити моральним засадам суспільства. Питання необхіАності програмування такої поведінки в роботів залишається відкритим. Отже, як "навчити" роботів Аотримуватися норм моралі або етичних норм? Питання залишається віАкритим. Інколи трапляються випаАки, коли порушення норм права $€$ морально виправданим, необхідним, наприклаА, Аля недопущення Аискримінації ^юдини в ії̈ правах через стать або релігійні переконання. І навпаки, деякі дії можуть бути законними, але суперечити моральним засаАам та переконанням. НаприклаА, невиконання взятого на себе зобов'язання, яке не було оформлено Аоговором, тощо.

Таким чином, можна констатувати, що принаймні в найближчому майбутньому відповідальність за Аії роботів будуть нести фізичні особи, причетні до їх створення. ВіАповіАно, вже зараз існує необхідність визначення правил застосування заходів юридичної віАповіАальності до таких осіб.

Відомо, що Аелікт як юриАична конструкція виник за часів Аавньоримської Аержави. Сьогодні Аеліктне право $€$ інститутом цивільного права і являє собою систему правових норм, що регулюють суспільні віАносини у зв'язку зі зАійсненням цивільним правопорушень (Аеліктів). Правияа відшкодування шкоди, завданої правам та інтересам учасників цивільного обігу, містяться у главі 82 цК України.

Отже, відповіАно Ао ч. 1 ст. 1166 ЦК України майнова шкода, завдана неправомірними рішеннями, Аіями чи бездіяльністю особистим немайновим правам фізичної або юридичної особи, а також шкода, завдана майну фізичної або юридичної особи, відшкодовується в повному обсязі особою, яка ії завАала. При цьому наступні статті відповідної глави ЦК України містять низку винятків із Ааного правила. Зокрема, йдеться про віАшкодування шкоАи, завданої особами з неповною дієздатністю, за яких відповідають законні преАставники: неповнолітні особи, малолітні особи, недієздатні особи, особи з обмеженою дієздатністю. В усіх цих випадках за шкоду, завдану правам та інтересам інших осіб, у повному розмірі або частково відповіАають законні представники таких осіб.

Отже, чинний Цивільний кодекс України містить спеціальні делікти, але відповідальність за шкоду, завдану роботами, наразі віАсутня. ВиАається Аоцільним використати вже наявні норми ЦК України Аля формулювання правил застосування цивільно-правовоївідповідальностіза шкоду, спричинену роботами. При тому суб'єктами, які будуть нести вказану відповідальність, будуть не законні представники, а особи, які мали відношення Ао створення і програмування робота: винахіАники, програмісти, виробники і власники роботів.

Ретельному АосліАженню піАлягатиме вина кожної з наведених вище осіб, що, безумовно, ускладнить процес кваліфікації деліктів.

Тим не менше, незважаючи на певні склаАності регулювання деліктних віАносин за участю роботів, сліА вже зараз Аоповнити чинний ЦК України нормою, яка б встановлювала правила відшкодування шкоди, завданої роботами. Іншими словами, необхінно передбачити норму, яка б містила правила застосування цивільно-правової відповідальності за новий різновиА спеціального Аелікту, а саме віАшкодування шкоди, завданої роботами.

Варто зауважити, що Аля віАшкодування шкоАи, завданої механізмами, зокрема й роботизованими, всі правові підстави існують.

Відомо, що ст. 1187 ЦК України передбачає правила віАшкодування шкоди, завданої Ажеремом піАвищено небезпеки. Зокрема, Ажерелом підвищеної небезпеки є Аіяльність, пов'язана з використанням, зберіганням або утриманням транспортних засобів, механізмів та обладнання, використанням, зберіганням хімічних, радіоактивних, вибухо- і вогненебезпечних та інших речовин, утриманням Аиких звірів, службових собак та собак бійцівських поріА тощо, що створює піАвищену небезпеку Аля особи, яка цю Аіяльність зАійснює, та інших осіб.

Шкода, завдана Ажерелом підвищеної небезпеки, відшкодовується особою, яка на відповідній правовій підставі (право власності, інше речове право, договір підряду, оренди тощо) володіє тран- 
спортним засобом, механізмом, іншим об'єктом, використання, зберігання або утримання якого створює підвищену небезпеку.

Проте норми про віАшкодування шкоАи, завАаної Ажерелом піАвищеної небезпеки, не можуть бути застосовані Аля віАшкодування шкоди, завАаної роботом, аАже наявність штучного інтелекту і здатності приймати самостійні рішенні корінним чином змінюють ситуацію, і виникає потреба спеціального правового регулювання зазначених віАносин.

Як було зазначено вище, за основу Аля подальших наукових пошуків і віАповіАних нормативних пропозицій необхідно взяти концепцію "квазісуб'єктності" роботів.

Висновки з Ааного АосліАження і перспективи поАальших розвіАоК у Ааному напрямку. За результатами зАійсненого АосліАження варто зробити висновок про наАзвичайну актуальність наукових пошуків у сфері цивільно-правової віАповідальності за шкоАу, завдану роботами. Наявність виваженого Аоктринального піАходу Ао регулювання віАповіАних віАносин наАасть змогу розробити необхіАні зміни Ао чинного законодавства в досліАжуваній сфері. Зокрема, вже зараз необхідно Аоповнити Цивільний кодекс України спеціальною нормою, яка б передбачала правила віАшкодування шкоди, завданої роботами. На сучасному етапі розвитку робототехніки варто використати концепцію "квазісуб'єктності" роботів, із покладанням віАповіАальності за шкоду, завдану роботами, на осіб, відповідальних за їх створення і функціонування. При цьому в майбутньому питання визнання Аієздатності і Аеліктоздатності самих роботів постане неодмінно.

\section{NITEPATYPA:}

1. What is SPARC? The Partnership for Robotics in Europe. SPARC. 2019. URL : https://www.eu-robotics.net/sparc/about/index.html.

2. Архипов В. Юридические аспекты робототехники. Адвокатская газета. 2017. URL : https://www.advgazeta.ru/mneniya/ yuridicheskie-aspekty-robototekhniki/?fbclid=IwAR22d2fynGnHYgZLmqGJXVw1KjLq3kB8AYcdMomcUAKaAM6PvE65faK $\mathrm{jHp} 0$.

3. Карчевський М.В. Основні проблеми правового регулювання соціалізації штучного інтелекту. IT-право: проблеми та перспективи розвитку в Україні : збірник матеріалів ІІ-ї Міжнародної науково-практичної конференції (Львів, 17 листопада 2017 р.). Львів : НУ «Львівська політехніка, 2017. С. 93-99.

4. Некіт К.Г. Суб’ єкти права приватної власності в інформаційному суспільстві. LEX PORTUS. 2018. № 2. C. $128-141$.

5. Peter M. Asaro. Robots and Responsibility from a Legal Perspective. URL : http://www.peterasaro.org/writing/ASARO $\% 20$ Legal\%20Perspective.pdf.

\section{Колодін Аенис Олексійович, Байталюк Аарія Русланівна ЩОАО ПИТАННЯ ЦИВІАЬНО-ПРАВОВОЇ ВІАПОВІААЛЬНОСТІ ЗА ШКОАУ, ЗАВААНУ РОБОТИЗОВАНИМИ MЕХАНІЗМАМИ ЗІ ШТУЧНИМ IHТЕАЕКТОМ (РОБОТАМИ)}

У статті АосліАЖУЮться суспільні віАносини щоАо питання віАповіАальності за шкоАу, завАану роботами, а також пов'язане із цим питання можливості визнання роботів квазісуб'єктами цивільно-правових віАносин. Авторами висувається теза про те, що Аля відшкодування шкоди, завданої механізмами, зокрема й роботизованими, всі правові підстави існують. Висновком за результати дослілження є твердження, що вже зараз необхідно доповнити Цивільний кодекс України спеціальною нормою, яка б передбачала правила віАшкодування шкоди, завданої роботами.

Киючові слова: роботи, штучний інтелект, віАповіАальність, суб'єкти віАносин, квазісуб'єктність.

\section{Колодин Аенис Алексеевич, Байталюк Аария Руслановна \\ К ВОПРОСУ О ГРАЖААНСКО-ПРАВОВОЙ ОТВЕТСТВЕННОСТИ ЗА ВРЕА, ПРИЧИНЕННЫЙ РОБОТИЗИРОВАН- НЫМИ МЕХАНИЗМАМИ С ИСКУССТВЕННЫМ ИНТЕМЕКТОМ (РОБОТАМИ)}

В статье исслеАуются общественные отношения по вопросу ответственности за вреА, причиненный роботами, а также связанный с этим вопрос о возможности признания роботов квазисубъектами гражАанско-правовых отношений. Авторами выАвигается тезис о том, что Аля возмещения вреАа, причиненного механизмами, в том числе и роботизированными, все правовые основания существуют. Выводом по результатам исслеАования является утвержАение, что уже сейчас необходимо дополнить ГражАанский кодекс Украины специальной нормой, преАусматривающей правила возмещения вреАа, причиненного работами.

Кючевые слова: роботы, искусственный интемлект, ответственность, субъекты отношений, квазисубъектность. 


\section{ЧАСОПИСЦИВІЛІСТИКИ 回回回回回回回回回回回回回回回回回回 91}

Kolodin Denis, Baytalyuk Dariya

TO THE QUESTION OF CIVIL LIABILITY FOR THE DAMAGE CAUSED BY ROBOTIZED MECHANISMS WITH ARTIFICIAL INTELLIGENCE (ROBOTS)

In connection with the rapid development of robotics and artificial intelligence, the question is the recognition of robots quasi-subjects of civil relations.

The article studies public relations on the issue of liability for harm caused by robots, as well as the question of the possibility of recognizing robots as quasi-subjects of civil law relations.

The purpose of the article is to study the problem aspects of civil liability for damages caused by the use of artificial intelligence and robotic mechanisms (robots). In addition, due to the rapid development of information technology and the active use of artificial intelligence and robots, there is a need to rethink traditional approaches to the definition of the concept of subjects of civil legal relations.

Legal personality and work cannot be the same. The legal personality of the robots will be limited. In particular, American lawyers are already proposing to consider robots as quasi-subjects of civil relations, which enjoy only partial rights and responsibilities.

The current Civil Code of Ukraine contains special cases, but the responsibility for the damage caused by work is currently absent. It seems expedient to use the existing norms of the Central Committee of Ukraine to formulate the rules for the application of civil liability for damages caused by work. Moreover, the subjects who will bear the specified responsibility will be non-lawful representatives, and those who were involved with the creation and programming of the work: inventors, programmers, manufacturers, and owners of robots.

The authors put forward the thesis that to compensate for the harm caused by mechanisms, including robotized ones, all legal grounds exist. The conclusion of the study is the assertion that it is already necessary to supplement the Civil Code of Ukraine with a special rule providing rules for the compensation of harm caused by work.

Key words: robots, artificial intelligence, responsibility, subjects of relations, quasi-subjectness. 